\title{
ARE THERE BORDER EFFECTS IN THE EU WAGE FUNCTION?
}

\author{
PETER HUBER \\ MICHAEL PFAFFERMAYR \\ YVONNE WOLFMAYR
}

CESIFO WORKING PAPER NO. 1880

CATEGORY 10: EMPIRICAL AND THEORETICAL METHODS

DECEMBER 2006

An electronic version of the paper may be downloaded

- from the SSRN website:

- from the RePEc website:

- from the CESifo website:

www.SSRN.com

www.RePEc.org

www.CESifo-group.de 


\title{
ARE THERE BORDER EFFECTS IN THE EU WAGE FUNCTION?
}

\begin{abstract}
We estimate a linear approximation of the market potential function for Europe as derived in geography and trade models. Using a spatial econometric estimation approach, border effects are identified by a differential impact of other regions purchasing power, depending on whether two regions are located within the EU15 or outside the EU15. We find that intra EU15-borders have an insignificant but external borders a significant effect on regional wage structures. We illustrate the magnitude of EU external border effects by simulating the enlargement of the EU in May 2004. Our results suggest a large impact of the border for new member states, but a relatively small one for old members.
\end{abstract}

JEL Code: F10, R12, F12, C21.

Keywords: market potential, border effects, spatial econometrics.

Peter Huber
Austrian Institute of Economic Research
PO-Box 91
1103 Vienna
Austria
Peter.Huber@wifo.ac.at

Yvonne Wolfmayr

Austrian Institute of Economic Research

PO-Box 91

1103 Vienna

Austria

yvonne.wolfmayr@wifo.ac.at

December 7, 2006

The authors would like to thank Thiess Büttner, Werner Mueller and the participants of the CESifo Conference on the Euro Area Enlargement and the AccessLab workshop in Vienna for helpful comments. We are also grateful to Irene Langer from the Austrian Institute of Economic Research for help with the data and research assistance. Lastly, we gratefully acknowledge financial support from the Austrian National Bank, Jubilaeumsfond Grant Nr. 10057 and from the 5th framework programme project AccessLab. 


\section{Are there Border Effects in the EU Wage Function? 2}

\section{INTRODUCTION}

Since the fall of the Iron Curtain and the opening-up of the Central and Eastern European Countries (CEEC) at the beginning of the nineties major steps of economic integration have been undertaken between the EU, EFTA countries and the CEEC. Examples are the reduction of tariffs and other trade barriers with the completion of the Europe Agreements and the introduction of a pan-European cumulative tariff system which replaced the complex system of rules of origin in the European Union. These steps culminated in the accession of eight countries from the region in May 2004.

This accession has been associated with a number of concerns amongst which regional issues and labour market effects figured most prominently. In the public debate concerns about the intensified competition among border regions have often been voiced. However, the majority of economic studies so far mainly focussed on the analysis of wage and employment effects of trade integration for single countries (specifically, the US and the UK). The regional perspective still seems under-researched, although new economic geography models suggest major regional impacts of integration. These models offer two central predictions on the spatial structure of wages and the effects of integration on wages in border regions. First, falling transport costs across national borders (a synonym for integration in these models) may change the spatial structure of wage rates within a country (see Krugman and Livas, 1996; Fujita, Krugman and Venables, 1999; Paluzzie, 2001; Crozet and Koenig-Soubeyran, 2004) as well as between countries. As recently pointed out for instance by Brülhart, Crozet and Koenig-Souberain (2004), the reduction in cross border transport costs implied by EU enlargement may change 


\section{Are there Border Effects in the EU Wage Function? 3}

the spatial structure of EU countries and accession countries. Second, economic geography models predict that regional wage levels follow a non-linear version of the market potential function proposed by Harris (1954).

In this paper we use these two predictions of economic geography models to test the significance of border effects of EU15-internal and external borders and thus provide evidence on the size of border effects in the European wage function. We linearly approximate the non-linear potential function implied by the core-periphery model to derive a simple linear specification (see also Combes and Lafourcade, 2001 or Mion, 2004). In contrast to the existing literature, which mainly follows the seminal work by Hanson (2005) for the US and provides a number of estimations of the market potential function for the EU15 (Niebuhr, 2004, 2005) as well as individual EU countries (Roos, 2001; Brakman, Garretsen and Schramm, 2004; De Bruyne, 2003; Mion 2004) and groups of EU countries (see Head and Mayer, 2005) we explicitly model border effects. We argue that in a European context this extension may be important because on the one hand the countries in the EU are more strongly integrated than separate nations, but on the other hand they may not (yet) be fully integrated. This would lead us to expect some cross border interdependence of wages, which is less pronounced than within countries.

We estimate our specification for a cross-section of NUTSII regions encompassing the EU15, the largest new EU member states as well as Switzerland and Norway. In contrast to the literature on border effects in goods prices and trade in the EU (see Nitsch, 2000, Beck and Weber, 2003) which finds sizeable intra EU border effects, our findings suggest that the impact of GDP and wages of regions across borders of countries within the EU15 on regional wage levels does not differ 


\section{Are there Border Effects in the EU Wage Function? 4}

significantly from that of regions within the same country. However, there are still substantial border effects with respect to EU external borders.

Finally, we illustrate the size of these EU external border effects by simulating the imlication of the accession of the CEEC to the EU15 by assuming that in the long run border effects between EU15 and new member states will converge to those found currently among the EU15. These calculations suggest that border effects between the EU15 and accession countries are strongest in the border regions of the accessions countries, while most regions of the incumbent countries remain virtually unaffected. Overall, our empirical results thus suggest that accounting for border effects and steady state real wage differences in market potential estimations is important at least when focusing on European countries and that a reduction of border impediments has particularly strong effects on regions closer to the EU15 border.

\section{THE ECONOMETRIC SPECIFICATION AND MARKET POTENTIAL FUNCTION}

The starting point in deriving our empirical specification is the structural market potential function which has also been termed the wage function in recent literature. As pointed out by Fujita, Krugman and Venables (1999) this function which relates the nominal wage rate $w_{i}$ in region $i(i=1 \ldots N)$ to the spatially weighted sum of purchasing power (in terms of nominal GDP, $y_{i}$ ) of its neighboring regions, has been one of the work horse models of regional science at least since the seminal work of Harris (1954). This function, however, has recieved its theoretical foundation only recently in the economic geography models of Krugman (1991a), 


\section{Are there Border Effects in the EU Wage Function? 5}

Helpman (1998) and Hanson (2005). These models comprise a differentiated manufacturing good which is produced under increasing returns and enters utility in terms of a CES subutility function, and a homogenous good. The overall utility function is Cobb-Douglas with expenditure shares $0<\mu<1$ for the differentiated good and $1-\mu$ for the homogenous one. While the differentiated good exhibits transportation costs depending on distance, the homogenous good is costlessly tradable. The price of the homogenous good is normalized to 1 so that the overall price index in region $i$ is given by $T_{i}^{\mu}$. The relation between the nominal wage rate $w_{i}$ in region $i$ and the spatially weighted sum of purchasing power is based on the following two equilibrium conditions (Krugman, 1991, Hanson, 2005).

(1) $\frac{w_{i}}{T_{i}^{\mu}}=\frac{w_{j}}{T_{j}^{\mu}}=\frac{\bar{w}}{\bar{T}^{\mu}}=\bar{\omega}, \quad i \neq j \Rightarrow T_{j}=\left(\frac{w_{j}}{\bar{\omega}}\right)^{\frac{1}{\mu}}$

(2) $w_{i}=\left[\sum_{j=1}^{N} y_{j} f\left(d_{i j}\right)^{\sigma-1} T_{j}^{\sigma-1}\right]^{\frac{1}{\sigma}}$,

where the subscripts $i$ and $j$ index regions and $\sigma>1$ denotes the elasticity of substitution between any two variants of manufacturing goods.

Equation (1) states that in equilibrium real wages are equalized across all regions so that there is no incentive for workers to migrate. Forward and backward linkages induce spatial concentration of workers and firms and constitute the well known centripetal and centrifugal forces in the model (Krugman, 1991) ${ }^{1}$. The equilibrium wage rate of region $i$ is determined by the market potential equation (2), which forms the basis of our econometric specification. Here, region $j^{\prime}$ s spatial weight is based on its distance to region $i, d_{i j}$, according to the distance decay 


\section{Are there Border Effects in the EU Wage Function? 6}

function $f\left(d_{i j}\right)$ with, $f\left(d_{i j}\right)<1$ and $f\left(d_{i j}\right)^{\prime}<0$. Taking the logs of (2) gives

(3) $\ln w_{i}=\frac{1}{\sigma} \ln \left(\sum_{j=1}^{N} y_{j} f\left(d_{i j}\right)^{\sigma-1} T_{j}^{\sigma-1}\right)$.

Following Roos (2001), Mion (2004), Hanson (2005) and Niebuhr (2004) and others, we first eliminate the empirically unobservable price index $\left(T_{j}\right)$ in equation (2) to derive an estimable specification. For this, we follow the literature and substitute equation (1) into (3) to derive:

(4) $\begin{aligned} \ln \left(w_{i}\right) & =\frac{1}{\sigma} \ln \left(\sum_{j=1}^{N} y_{j} f\left(d_{i j}\right)^{\sigma-1}\left(\frac{w_{j}}{\bar{\omega}}\right)^{\frac{\sigma-1}{\mu}}\right)= \\ & =\frac{1-\sigma}{\sigma \mu} \ln (\bar{\omega})+\frac{1}{\sigma} \ln \left(y_{i} w_{i}^{\frac{\sigma-1}{\mu}}+\sum_{j \neq i}^{N} y_{j} w_{j}^{\frac{\sigma-1}{\mu}} f\left(d_{i j}\right)^{\sigma-1}\right) .\end{aligned}$

We introduce border effects by parametrizing $f\left(d_{i j}\right)^{\sigma-1}$. For this we define three sets of $i j$ pairs of regions. First, $\mathcal{F}_{0}$ is the set of all region pairs. This set of regions forms the base against which we measure the border effects. Second, $\mathcal{F}_{E U}$ denotes the set of pairs of regions $i$ and $j$ that are located within the EU15 but in different countries. Third, the set $\mathcal{F}_{N E U}$ comprises the all variants of $i j$ pairs, where one region is located inside the EU15 and the other outside or where both of them are located in different countries outside the EU15. Finally, regional pairs $i$ and $j$ that are located within the same EU15 or non-EU15 country neither belong to $\mathcal{F}_{E U}$ nor to $\mathcal{F}_{N E U}$. Based on these three sets, we parameterize the distance decay function $f\left(d_{i j}\right)^{\sigma-1}$ as follows:

(5) $\quad f\left(d_{i j}\right)^{1-\sigma}=\left\{\begin{array}{c}\left(\rho_{0}+\rho_{E U}\right) \frac{e^{-\alpha d_{i j}}}{c} i j \in \mathcal{F}_{E U} \\ \left(\rho_{0}+\rho_{N E U}\right) \frac{e^{-\alpha d_{i j}}}{c} i j \in \mathcal{F}_{N E U} \\ \rho_{0} \frac{e^{-\alpha d_{i j}}}{c} i j \notin \mathcal{F}_{E U} \text { and } i j \notin \mathcal{F}_{N E U}\end{array}\right.$ 


\section{Are there Border Effects in the EU Wage Function? 7}

where $c=1+\max _{i} \sum_{i \neq j} e^{-\alpha d_{i j}}$ and the parameters $\rho_{0}, \rho_{E U}, \rho_{N E U}$ measure the relative border effects. In the presence of EU15 border effects we conjecture $\rho_{E U}<0, \rho_{N E U}<0$ and $\rho_{E U}>\rho_{N E U}$. Following Mion (2004) we approximate the sum of the decay functions $f\left(d_{i j}\right)^{\sigma-1}$ by a constant so that

$$
\begin{aligned}
\sum_{j=1, j \neq i}^{N} f\left(d_{i j}\right)^{\sigma-1}= & \rho_{0} \sum_{j \neq i \text { and } i j \in \mathcal{F}_{0}} \frac{e^{-\alpha d_{i j}}}{c}+ \\
& \rho_{E U} \sum_{j \neq i \text { and } i j \in \mathcal{F}_{E U}} \frac{e^{-\alpha d_{i j}}}{c}+ \\
& \rho_{N E U} \sum_{j \neq i \text { and } i j \in \mathcal{F}_{N E U}} \frac{e^{-\alpha d_{i j}}}{c} \approx \rho .
\end{aligned}
$$

This formulation implies that the spatial weight and, hence, the market potential of a region decreases with its distance to its neighbors, all else equal. A similar spatial weighting scheme has been proposed by Kelejian and Prucha (2005) who argue that it is less restrictive than a row normalized spatial weighting scheme used in much of the spatial econometrics literature. From an economic point of view it is preferable since it implies that the market potential of a region decreases the further away it is located from the other regions all else equal. ${ }^{2}$

Next we approximate the left and right hand side of (4) linearly around average values. In the Appendix ${ }^{3}$ this approximation is derived as

$$
\begin{aligned}
(6) \widetilde{w}_{i}= & K+\beta_{1} \sum_{j \neq i \text { and } i j \in \mathcal{F}_{0}} \Theta_{i j}^{0} \widetilde{w}_{j}+\beta_{2} \sum_{j \neq i \text { and } i j \in \mathcal{F}_{E U}} \Theta_{i j}^{E U} \widetilde{w}_{j} \\
& +\beta_{3} \sum_{j \neq i \text { and } i j \in \mathcal{F}_{N E U}} \Theta_{i j}^{N E U} \widetilde{w}_{j}+\beta_{4} \widetilde{y}_{i}+\beta_{5} \sum_{j \neq i \text { and } i j \in \mathcal{F}_{0}} \Theta_{i j}^{0} \widetilde{y}_{j} \\
& +\beta_{6} \Theta_{j \neq i \text { and } i j \in \mathcal{F}_{E U}} \Theta_{i j}^{E U} \widetilde{y}_{j}+\beta_{7} \sum_{j \neq i \text { and } i j \in \mathcal{F}_{N E U}} \Theta_{i j}^{N E U} \widetilde{y}_{j},
\end{aligned}
$$

where $\widetilde{x}_{i}$ is the percentage deviation of $x_{i}$ from its mean $\bar{x}$ (i.e. $\widetilde{x}=\frac{x_{i}-\bar{x}}{\bar{x}}, x_{i} \in$ 


\section{Are there Border Effects in the EU Wage Function? 8}

$\left.\left\{w_{i}, y_{i}\right\}\right)$ and $K$ is a constant. The remaining parameters to be estimated are $\beta_{1}=\frac{\rho_{0}(\sigma-1)}{1+\sigma(\mu(1+\rho)-1)}, \beta_{2}=\frac{\rho_{E U}(\sigma-1)}{1+\sigma(\mu(1+\rho)-1)}, \beta_{3}=\frac{\rho_{N E U}(\sigma-1)}{1+\sigma(\mu(1+\rho)-1)}, \beta_{4}=\frac{\mu}{1+\sigma(\mu(1+\rho)-1)}$, $\beta_{5}=\frac{\rho_{0} \mu}{1+\sigma(\mu(1+\rho)-1)}, \beta_{6}=\frac{\rho_{E U} \mu}{1+\sigma(\mu(1+\rho)-1)}, \quad \beta_{7}=\frac{\rho_{0} \mu}{1+\sigma(\mu(1+\rho)-1)}$. The spatial decay functions $\Theta_{i j}^{k}$ with $k \in\{0, E U, N E U\}$ are defined in the Appendix .

In vector notation the empirical specification can thus be written as

$$
\begin{aligned}
\widetilde{\mathbf{w}}= & \beta_{1} \mathbf{W}^{0} \widetilde{\mathbf{w}}+\beta_{2} \mathbf{W}^{E U} \widetilde{\mathbf{w}}+\beta_{3} \mathbf{W}^{N E U} \widetilde{\mathbf{w}}+ \\
& \beta_{4} \widetilde{\mathbf{Y}}+\beta_{5} \mathbf{W}^{0} \widetilde{\mathbf{Y}}+\beta_{6} \mathbf{W}^{E U} \widetilde{\mathbf{Y}}+\beta_{7} \mathbf{W}^{N E U} \widetilde{\mathbf{Y}}+ \\
& \gamma \mathbf{Z}+\mathbf{u} .
\end{aligned}
$$

where $\mathbf{Z}$ is a vector of explanatory variables entering the regression to proxy for otherwise unobservable price and wage differences not captured by the model and also includes the constant $(K)$. $\mathbf{W}^{0}, \mathbf{W}^{E U}$ and $\mathbf{W}^{N E U}$ are the $N \times N$ spatial weighting matrices with $N$ being the number of regions. $\mathbf{u}$ denotes the vector of errors which may be spatially autocorrelated such that $\mathbf{u}=\phi \mathbf{W u}+\varepsilon, \varepsilon_{j} \sim \operatorname{iid}\left(0, \sigma_{\varepsilon}^{2}\right)$. Equation (7) forms the basic specification of the market potential function which is estimated below.

Several comments concerning this specification are in order. First, in its strict form the model implies a series of testable non-linear restrictions. In particular, from equation (7) it is easy to see that the following three restrictions should hold: $\frac{\beta_{1}}{\beta_{2}}=\frac{\beta_{5}}{\beta_{6}}=\frac{\rho_{0}}{\rho_{E U}}, \frac{\beta_{1}}{\beta_{3}}=\frac{\beta_{5}}{\beta_{7}}=\frac{\rho_{0}}{\rho_{N E U}}$ and $\frac{\beta_{2}}{\beta_{3}}=\frac{\beta_{6}}{\beta_{7}}=\frac{\rho_{E U}}{\rho_{N E U}}$. We use these restrictions to test the validity of the model in its strict form as specified in (7). Second, without the restrictions the structural parameters of the market potential function are not identified. We have seven relevant estimated parameters, but only five in the theoretical model. We thus confine our inference on the signs of the estimated 


\section{Are there Border Effects in the EU Wage Function? 9}

reduced form parameters. In this way, estimating border effects is, however, still possible. Third, the theoretical model is kept simple and, therefore, it is restrictive. There are a number of reasons to doubt the validity of the assumptions underlying equation (4). In particular, the theoretical model assumes real wage equalisation and identical technologies across regions and countries. This is, of course, unrealistic in the context of European data, in particular since our sample contains Central and Eastern European regions with productivity levels much lower than the EU15 average Aside from including border effects which account for imperfect real wage adjustments across national borders, we thus augment our baseline specification also by additional variables to control for the fact that real wages may not equilibrate across regions i.e. violate equation (1). In particular, we assume that average wages of regions differ due to their economic structure as measured by the share of agriculture and services in total employment (see also Niebuhr, 2004). Productivity differentials are captured by country group effects (Eastern European Countries, Non-EU15-EFTA countries, and EU15 countries which are the base).

\section{DATA AND ESTIMATION STRATEGY}

We use data of compensation per employee, nominal gross value added and sectorial employment for a total of 241 regions provided by Cambridge Econometrics which is based on information from the Eurostat New Cronos database. Data are at the NUTSII level and comprise regions from the EU15 member states and a subset of the largest new EU member states (Hungary, Poland and the Czech Republic) as well as Switzerland and Norway. To avoid problems with non-contingent 
spaces (due to lacking data on the Balkans) we omitted Greece from the data set. For German regions wage data (compensation per employee) are available only at the level of NUTSI. Since this would bias our spatial regressions we estimate proxies on NUTSII level using a fixed effects regression with region and time effects as well as GDP per capita, the share of workers in agriculture, manufacturing, construction and market services as well as the employment rate as explanatory variables. ${ }^{4}$

Table 1: Market potential by country

\begin{tabular}{|c|c|c|c|c|c|c|c|c|c|}
\hline & \multicolumn{5}{|c|}{ in bn Euro } & \multicolumn{4}{|c|}{ in percent } \\
\hline & Total & $\begin{array}{c}\text { outside a } \\
\text { country but } \\
\text { within EU15 }\end{array}$ & $\begin{array}{c}\text { outside a } \\
\text { country, } \\
\text { outside EU15 } \\
\text { or cross } \\
\text { border EU }\end{array}$ & $\begin{array}{l}\text { market } \\
\text { potential } \\
\text { shifted due to } \\
\text { accession }\end{array}$ & own country & $\begin{array}{c}\text { outside a } \\
\text { country but } \\
\text { within EU15 }\end{array}$ & $\begin{array}{c}\text { outside a } \\
\text { country, } \\
\text { outside EU15 } \\
\text { or cross } \\
\text { border EU }\end{array}$ & $\begin{array}{c}\text { market } \\
\text { potential } \\
\text { shifted due to } \\
\text { accession }\end{array}$ & own country \\
\hline Austria & 133,3 & 94,1 & 16,4 & 6,2 & 22,8 & 70,6 & 12,3 & 4,6 & 17,1 \\
\hline Belgium & 370,5 & 308,0 & 7,9 & 0,5 & 54,7 & 83,1 & 2,1 & 0,1 & 14,8 \\
\hline Switzerland & 183,8 & 0,0 & 153,6 & 0,0 & 30,2 & 0,0 & 83,6 & 0,0 & 16,4 \\
\hline Czech Republic & 109,2 & 0,0 & 105,5 & 96,6 & 3,7 & 0,0 & 96,6 & 88,4 & 3,4 \\
\hline Germany & 1111,8 & 302,3 & 57,5 & 15,2 & 752,0 & 27,2 & 5,2 & 1,4 & 67,6 \\
\hline Denmark & 27,2 & 21,5 & 1,3 & 0,4 & 4,5 & 78,8 & 4,7 & 1,6 & 16,4 \\
\hline Spain & 62,7 & 21,6 & 0,5 & 0,0 & 40,6 & 34,4 & 0,8 & 0,0 & 64,8 \\
\hline Finland & 8,4 & 3,5 & 0,3 & 0,1 & 4,6 & 41,1 & 4,0 & 0,8 & 54,8 \\
\hline France & 379,1 & 188,7 & 25,1 & 0,4 & 165,3 & 49,8 & 6,6 & 0,1 & 43,6 \\
\hline Hungary & 30,6 & 0,0 & 26,5 & 22,4 & 4,2 & 0,0 & 86,4 & 73,3 & 13,6 \\
\hline Ireland & 7,9 & 6,0 & 0,0 & 0,0 & 1,9 & 75,9 & 0,2 & 0,0 & 23,9 \\
\hline Italy & 229,6 & 79,9 & 21,5 & 1,5 & 128,2 & 34,8 & 9,3 & 0,6 & 55,8 \\
\hline Luxemburg & 33,9 & 32,4 & 1,5 & 0,1 & 0,0 & 95,6 & 4,4 & 0,2 & 0,0 \\
\hline Netherlands & 356,7 & 268,9 & 4,9 & 0,7 & 82,9 & 75,4 & 1,4 & 0,2 & 23,2 \\
\hline Norway & 14,5 & 0,0 & 9,9 & 0,0 & 4,6 & 0,0 & 68,4 & 0,0 & 31,6 \\
\hline Poland & 76,8 & 0,0 & 59,8 & 53,8 & 17,0 & 0,0 & 77,9 & 70,1 & 22,1 \\
\hline Portugal & 11,9 & 7,5 & 0,0 & 0,0 & 4,4 & 63,0 & 0,1 & 0,0 & 37,0 \\
\hline Sweden & 26,0 & 13,6 & 3,1 & 0,6 & 9,3 & 52,4 & 11,9 & 2,4 & 35,8 \\
\hline U.K. & 570,0 & 172,7 & 2,7 & 0,1 & 394,6 & 30,3 & 0,5 & 0.0 & 69,2 \\
\hline
\end{tabular}

For estimation we use a cross section of averages over the periods 1999-2002. ${ }^{5}$ The dependent variable is nominal compensation per employee. Regional income (purchasing power), is approximated by nominal gross value added. Additional controls are the share of workers in agriculture, in market and in non market services (manufacturing and construction being the base) as well an EFTA (Switzerland and Norway) and a CEEC-dummy (Czech Republic, Hungary and Poland). 
Are there Border Effects in the EU Wage Function? 11

Finally, distance is measured as the crow fly distance between the capitals of each NUTSII region.

Table 1 displays the distance weighted purchasing power (gross value added; GVA) of all accessible regions aggregated to the country level (column 1). Column 2 reports the average distance weighted purchasing power of regions either located in another country but within the EU15 (i.e. the members of $\mathcal{F}_{E U}$ ) and column 3 that in different countries outside the EU15 (i.e. the members of $\mathcal{F}_{N E U}$ ), while the mass of purchasing power affected by the EU accession of Czech Republic, Hungary and Poland is reported in column 4 . The residual in column 5 gives the purchasing power of the regions in their own country. Columns 6 - 8 report the corresponding breakdown in percent. This table corroborates the results of Brülhart, Crozet and Koenig-Souberain (2004) and of Niebuhr (2004) which indicate that the additional market potential provided by the new EU member states to the existing EU15's market is small relative to the potential for the old member states. Austria, Sweden and Germany are the countries to gain most in terms of market potential by enlargement, but even here the market potential outside the EU15 amounts to less than 5 percent.

For countries more distant to the new member states, such as Spain or Portugal, the additional market potential in the new member states is negligeable. In contrast, a substantial amount of the market potential for the new member states is located in the old EU member states. In the Czech Republic, Hungary, and Poland more than 70 percent of the total market potential is located in regions of the EU15.

A specific problem of the market potential function based on the above model is that many right hand side variables are endogenous. First, the model is not closed 
so that it ignores the fact that the income of a region is endogenous. Second, $\mathbf{W}^{0} \widetilde{\mathbf{w}}, \mathbf{W}^{E U} \widetilde{\mathbf{w}}$, and $\mathbf{W}^{N E U} \widetilde{\mathbf{w}}$ are endogenous as the vector of wage rates $\widetilde{\mathbf{w}}$ shows up on the left and in a spatially weighted form also on the right hand side of the regression. To overcome these endogeneity problems we apply the spatial GMestimator of Kelejian and Prucha (1999), proceeding in three steps. Based on an initial (IV) regression, we first estimate the model assuming $\phi=0$ by 2SLS which provides consistent estimates of the parameters and the residuals. Second, we estimate the spatial correlation parameter $\phi$ using the first stage residuals to solve the GM-conditions put forward by Kelejian and Prucha (1999). Third, the final estimation results are derived using a Cochrane-Orcutt type transformation $v_{i}^{*}(\widehat{\phi})=[(\mathbf{I}-\widehat{\phi} \mathbf{W}) \mathbf{v}]_{i}$ for all variables in the model and applying 2SLS on the transformed data. Kelejian and Prucha (1999) show that this procedure leads to consistent estimates in the presence of spatially correlated errors. They suggest to use the spatially lagged values of all untransformed exogenous variables as instruments. In addition, we also use other outside instruments for a region's nominal income (see Tables 2 and 3). However, we include only those instruments which pass the Sargan overidentifcation test. Shea's $R^{2}$ as well as as F-tests show that these instruments are relevant.

We estimate several different models to see whether our estimation results are robust. Model 1 is a reduced form (ignoring spatially weighted wage rates) and treats regional income as an exogenous variable. ${ }^{6}$ Model 2 is the same as Model 1 , but with regional income endogenous. Model 3 is the unrestricted structural form, which includes $\mathbf{W}^{0} \widetilde{\mathbf{w}}, \mathbf{W}^{E U} \widetilde{\mathbf{w}}$, and $\mathbf{W}^{N E U} \widetilde{\mathbf{w}}$, while Model 4 accounts for the restrictions as illustrated above. In both Models 3 and 4 regional income is also endogenous and instrumented properly. Although subject to nonlinear restrictions, 
Model 4 is linear in the variables, so in the first stage we can use OLS projecting all variables on the instruments and the exogenous variables. The second stage utilizes the first stage predictions of the endogenous variables and applies NLSQ to account for the nonlinear parameter restrictions mentioned above. ${ }^{7}$ In spatial econometric models the spatial decay parameter $\alpha$ is usually a fixed parameter. We set $\alpha=1 / 100$ (see Table 2 ). ${ }^{8}$ The estimation results also indicate significant spatial correlation of the error term (as evidenced by the significant Moran I-test of Kelejian and Prucha, 2001) so that the GM approach is indeed required.

\section{RESULTS}

The results (in Table 2) suggest that our control variables work well, indicating substantiality lower wages in the CEEC and higher ones in Switzerland and Norway (EFTA) as compared to the EU15. In addition, wages are significantly higher in regions with a high share of workers in market services, but lower in agricultural regions. Furthermore, experimentation with other variables suggest that the estimates are similar if we include a density indicator such as population per square kilometer to capture this effect. ${ }^{9}$ Also, the instruments work well enough to allow inferences on border effects, although some parameters (mostly those of the instrumented variables or of the income variables) are affected by multicollinearity. Specifically, in the unrestricted structural form models (model 3) this problem seems relevant.

Moving to the parameter estimates of our regressions we find a robust and significant positive effect of own regional income. This effect is however, smaller than that of other regions in the same country in all specifications. This is not 
Are there Border Effects in the EU Wage Function? 14

in line with theory which assumes zero transportation costs within a region and, hence, the highest impact of demand on wages. One of the reasons for this somewhat unexpected result could be the correlation with the other controls such as $\mathbf{W}^{0} \mathbf{y}$. While this result is unexpected, our results concerning the estimates of the reduced form parameters (model 1 and 2) suggest that the impact of gross value added of regions located in different countries of the EU15 (i.e. the members of $\left.\mathcal{F}_{E U}\right)$ on regional wages is not significantly different from the effect of equidistant regions in the same country. This implies that the hypothesis that the spatially weighted purchasing power of all regions and the spatially weighted purchasing power of regions in other EU countries exert the same impact cannot be rejected in the reduced form Models 1 and 2. According to these estimates national borders within the EU do not seem to be a major impediment to spillovers in the demand potential of other regions. This stylized fact also carries over to the model when considering the restricted full specification in model 4 . In this case too the impact the impact of gross value added of regions located in different countries of the EU15 on regional wages is not significantly different from the effect of equidistant regions in the same country.

The only model which disagrees with our finding of relatively small within EU15 border effects is Model 3. This model suggests that cross border wage effects within the EU15 are substantially lower than within countries, while with regard to income, we get the opposite result. ${ }^{10}$ This finding is difficult to interpret from a theoretical perspective. It seems to be mainly due to econometric problems with the specification and the instruments. As mentioned above, the parameters (in particular those of the instrumented variables) of this specification are strongly affected by multicollinearity which makes inferences based on this 
model problematic.

Table 2: Estimates of the spatial market potential function

Dependent variable is nominal wage rate, averages $1999-2002, \square=1 / 100$

\begin{tabular}{|c|c|c|c|c|c|c|c|c|}
\hline & \multicolumn{2}{|c|}{$\begin{array}{l}\text { model 1: reduced form, } \\
\text { OLS }\end{array}$} & \multicolumn{4}{|c|}{$\begin{array}{l}\text { model 2: reduced form, model 3: structural form, } \\
\text { IV IV }\end{array}$} & \multicolumn{2}{|c|}{$\begin{array}{l}\text { model 4: restricted } \\
\text { structural form, IV }\end{array}$} \\
\hline & b & $z$ & b & $z$ & b & $z$ & $\mathrm{~b}$ & $\mathrm{z}$ \\
\hline$w^{0} w$ & & 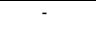 & & 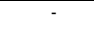 & 0,290 & 0,73 & 0,702 & $1,71+$ \\
\hline$w^{E U_{W}}$ & - & - & - & - & $-0,940$ & $-2,68$ *** & $-0,258$ & $-0,84$ \\
\hline $\mathrm{W}^{\mathrm{NEU}} \mathrm{w}$ & & 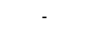 & & & $-3,152$ & $-3,60 * * *$ & $-1,309$ & $-1,90$ * \\
\hline y & 0,044 & $4,3 * * *$ & 0,093 & 1,92 * & 0,064 & $3,88^{* * *}$ & 0,035 & 2,21 ** \\
\hline$w^{0} y$ & 0,420 & $3,3 * * *$ & 0,364 & $2,62 * * \star$ & 0,560 & $3,70^{* * *}$ & 0,313 & 2,15 ** \\
\hline $\mathrm{W}^{\mathrm{EU} \mathrm{U}}$ & 0,295 & 1,5 & 0,468 & 1,64 * & 0,806 & 2,96 *** & $-0,115$ & a) \\
\hline$W^{N E U} y$ & $-0,671$ & $-2,2 * * *$ & $-0,396$ & $-0,89$ & 0,821 & $1,55+$ & $-0,583$ & a) \\
\hline Share of workers, non-market services & $-0,086$ & $-1,4+$ & $-0,040$ & $-0,50$ & $-0,062$ & $-0,98$ & $-0,149$ & $-2,33 \star \star$ \\
\hline Share of workers, market services & 0,420 & $5,3^{* * *}$ & 0,293 & 2,10 ** & 0,379 & $4,67 * * *$ & 0,422 & $4,86^{\star * * *}$ \\
\hline Share of workers, agriculture & $-0,033$ & $-2,2 * \star$ & $-0,027$ & $-1,58+$ & $-0,035$ & $-2,37^{\star * *}$ & $-0,039$ & $-2,45$ ** \\
\hline East & $-0,657$ & $-11,3^{\star \star}$ & $-0,650$ & $-11,46$ *** & $-0,439$ & $-5,48 * \star \star *$ & $-0,537$ & $-6,70^{* \star *}$ \\
\hline Efta & 0,514 & 8,52 ** & 0,508 & $8,12^{\star \star \star}$ & 0,391 & $5,57^{\star \star \star *}$ & 0,487 & $7,91^{\star \star \star}$ \\
\hline$R^{2}$ & 0,74 & & 0,74 & & 0,84 & & 0,83 & \\
\hline$\square$ & 0,03 & & 0,03 & & 0,03 & & & \\
\hline$\square$ & 4,26 & & 4,60 & & 5,60 & & - & \\
\hline Moran I (p-value) & 0,000 & & 0,000 & & 0,000 & & - & \\
\hline \multicolumn{9}{|l|}{ Instruments } \\
\hline Relevance: Shea partial $R^{2}$ for $W^{0} w$ & - & & - & & 0,870 & & - & \\
\hline Relevance: Shea partial $R^{2}$ for $W^{E U} W$ & - & & 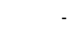 & & 0,826 & & - & \\
\hline Relevance: Shea partial $R^{2}$ for $W^{N E U} W$ & - & & & & 0,587 & & - & \\
\hline Relevance: Shea partial $R^{2}$ for $y$ & - & & 0,046 & & 0,337 & & - & \\
\hline Validity, Sargan test (p-value) & - & & 0,217 & & 0,127 & & - & \\
\hline Endogeneity, Wu-Hausman (p-value) & - & & 0,284 & & 0,285 & & - & \\
\hline \multicolumn{9}{|l|}{ F-tests on border effects ( $p$-value) } \\
\hline $\mathrm{W}: \square_{E U}=0, \square_{\text {non } E U}=0$ & - & & - & & 0,001 & & 0,085 & \\
\hline $\mathrm{W}: \mathrm{EU}_{\mathrm{EU}}=\square_{\mathrm{h} n \mathrm{n}} \mathrm{EU}$ & & & & & 0,003 & & 0,170 & \\
\hline$y: \square_{E U}=0, \square_{n o n: E U}=0$ & 0,013 & & 0,012 & & 0,012 & & & \\
\hline $\begin{array}{l}\mathrm{y}: \beth_{\mathrm{EU}}=\mathrm{Chon}_{\mathrm{I}} \mathrm{EU} \\
\text { Implied theoretical restriction }\end{array}$ & 0,003 & & 0,012 & & 0,903 & & 0,026 & \\
\hline
\end{tabular}

Notes: In model $1 \mathrm{y}$ is exogneous, while it is endogenous in models $2-4 . \mathrm{W}^{0} \mathrm{~W}, \mathrm{~W}^{\mathrm{EU}} \mathrm{W}$ and $\mathrm{W}^{\mathrm{NEU}} \mathrm{W}$ are always treated as endogenous variables. Instruments comprise spatially lagged values of the exogenous variables. In models 2-4 additionally, country GDP, area, density Sargan test in the second stage did not reject. All estimates and its standard errors are corrected for spatially autocorrelated errors follwing Kelejian and Prucha (1999). Spatial weigths are $W_{i=} \exp \left(-d_{j} / 100\right) /\left(1+\max W_{i}\right)$ where $\max W_{i}$ is the maximum of the row of spatial weighting matrix whic is not normalized ; *** significant at $1 \%$; ** significant at $5 \%$; "significant at $10 \%$; +significant at $15 \%$; a) Implied by weighting
restriction.

Thus while EU15 internal borders do not seem to be a major impediment to cross border spillovers in the regional wage structure, the differential impact of the spatially weighted purchasing power of regions from within the EU15 as compared to regions outside the EU15 is robust and substantial. In all estimated specifications (again with the exception of regional income in Model 3) the impact of the purchasing power of EU15 regions $\left(\mathbf{W}^{E U}\right)$ on wages in other EU15 regions is significantly higher than observed with EU15-external borders $\left(\mathbf{W}^{N E U}\right)$. Further- 
Are there Border Effects in the EU Wage Function? 16

more, in all models, with the mentioned exception of Model 3, the corresponding parameters are significantly smaller than zero. This is observed in both the coefficients of spatially weighted wage rates and in spatially weighted income. The F-test of no external EU15 border effects rejects in all but one cases (which again is model 3). Thus the general view emerges that spatial spillovers in wages and income levels across external borders of the EU15 are substantially lower than across EU15-internal borders.

Our results so far indicate that the impact of GDP of regions across borders of countries within the EU15 on regional wage levels in general does not statistically differ from that of regions within the same country. Our results, however, also suggest that external borders of the EU15 are a major impediment to trade and factor mobility, leading to pronounced extra-EU15 border effects irrespective of the specification chosen. To illustrate the size of these effects, we perform a simulation, using the estimated coefficient of the within EU15 vs. EU15 - non EU15 market potential model for the most recent enlargement episode of the new member states of the EU in our sample (Czech Republic, Hungary and Poland).

We base these simulations on the cross section estimation results reported in Table 2 by setting up an experiment of thought, asking how big the additional change in the growth rate of wages would have been in the absence of EU15 external border effects as compared to the base of a $14 \%$ increase in nominal wages over 1991-2002 in the sample. In this way, we are able to base our projections on the estimated linear approximation without relying on level information which cannot be inferred from the estimated model. Since these simulations are based on crosssection estimates the resulting wage effects reflect long run adjustments. Also, they reflect the influence of market potential and the change in border effects 
due to accession only, ignoring other major influences like productivity changes or pressures on factor price equalization resulting from increased and liberalized trade.

Table 3: The estimated impact of EU-enlargement

\begin{tabular}{|c|c|c|c|c|c|c|c|c|c|c|}
\hline \multirow[b]{3}{*}{ Austria } & & \multicolumn{3}{|c|}{$\begin{array}{l}\text { GDP per capita-devation } \\
\text { from EU-mean }\end{array}$} & \multicolumn{3}{|c|}{$\begin{array}{c}\text { hypothetical growth } \\
\text { differential in percentage } \\
\text { points, reduced form, model } \\
2\end{array}$} & \multicolumn{3}{|c|}{$\begin{array}{c}\text { hypothetical growth } \\
\text { differential in percentage } \\
\text { points, structural form, } \\
\text { model } 4\end{array}$} \\
\hline & & EU15 & $\begin{array}{c}\text { New } \\
\text { members }\end{array}$ & Efta & EU15 & $\begin{array}{c}\text { New } \\
\text { members }\end{array}$ & Efta & EU15 & $\begin{array}{c}\text { New } \\
\text { members }\end{array}$ & Efta \\
\hline & 1 & 49,53 & & & 1,09 & & & 0,57 & & \\
\hline Belgium & 2 & 36,27 & & & 0,07 & & & 0,04 & & \\
\hline Switzerland & 3 & & & 64,89 & & & 0,00 & & & 0,00 \\
\hline Czech Republic & 4 & & $-77,00$ & & & 27,97 & & & 13,03 & \\
\hline Germany & 5 & 14,92 & & & 0,78 & & & 0,41 & & \\
\hline Denmark & 6 & 44,48 & & & 0,23 & & & 0,12 & & \\
\hline Spain & 7 & $-15,65$ & & & 0,00 & & & 0,00 & & \\
\hline Finland & 8 & 17,37 & & & 0,02 & & & 0,01 & & \\
\hline France & 9 & 36,01 & & & 0,03 & & & 0,02 & & \\
\hline Hungary & 10 & & $-74,02$ & & & 12,20 & & & 5,69 & \\
\hline Ireland & 11 & 1,45 & & & 0,00 & & & 0,00 & & \\
\hline Italy & 12 & $-12,44$ & & & 0,19 & & & 0,10 & & \\
\hline Luxemburg & 13 & 65,41 & & & 0,10 & & & 0,05 & & \\
\hline Netherlands & 14 & 8,04 & & & 0,13 & & & 0,07 & & \\
\hline Norway & 15 & & & 45,20 & & & 0,00 & & & 0,00 \\
\hline Poland & 16 & & $-78,70$ & & & 11,96 & & & 5,70 & \\
\hline Portugal & 17 & $-54,22$ & & & 0,00 & & & 0,00 & & \\
\hline Sweden & 18 & 33,79 & & & 0,12 & & & 0,07 & & \\
\hline U.K. & 19 & 7,27 & & & 0,01 & & & 0,00 & & \\
\hline
\end{tabular}

Figure 1 (at the end of the text) presents the simulated wage effects in the form of a map. Table 3 summarizes the simulation results at the level of countries. Three main findings emerge. First, wage effects due to a reduction of cross border transport costs (border effects) in the process of EU enlargement are of a much higher magnitude for the new EU member states in the sample than for EU15 countries. Second, regions closest to the borders of the "old" and "new" EU are to gain most in terms of wage increases. Third, the combination of larger wage effects in the new member states and in border regions implies that regional disparities 
in wage rates within the new member states are likely to increase as well, since border regions have also been preferred regions in the period before accession ${ }^{11}$

In particular, our simulations suggest that wage growth in regions in the new member states near to the EU15 border should have been by 12 to 27 percentage points (Model 2) or 6 to 13 percentage points (Model 4) higher, relative to the actual development, if border effects had been of the same magnitude as within the EU15. The impact on EU15 regions is of substantially smaller magnitude and changes of relevant size are predicted for Austria and Germany only. Finally, regions more distant from the borders of the EU15 are more or less unaffected. The results of Model 2 for the EU15 countries indicate the most pronounced wage effects for Austria (1.1 percentage points), followed by Germany (0.8), Denmark, Sweden and Italy. Within the group of the three new member countries, the Czech Republic is to be most affected.

\section{CONCLUSIONS}

In this paper we estimate a linear approximation of the market potential function as derived from geography and trade models. This model relates the wage rate in a region to its own and the spatially weighted purchasing power of the other regions. Using a spatial econometric estimation approach, we identify border effects differing between regions (i) in different countries within the EU15 or (ii) outside the EU15. In contrast to the existing literature, we thus explicitly model border effects and potential differences in steady state real wage levels.

Our major findings with respect to these estimates suggest that the impact of GDP and wages of regions across borders of countries within the EU15 on 


\section{Are there Border Effects in the EU Wage Function? 19}

regional wage levels does not differ from that of regions within the same country. However, there are still substantial border effects with respect to external borders of the EU15. External borders of the EU15 are a major impediment to trade and factor mobility, leading to pronounced extra-EU15 border effects irrespective of the specification chosen. In consequence EU-integration may have substantial effects on the wage structures of individual countries. To illustrate the size of these effects, we perform a simulation, using the estimated coefficient of the within EU15 vs. EU15 - non EU15 market potential model for the most recent enlargement episode of the new member states of the $\mathrm{EU}$ in our sample. This simulation exercise suggests that the accession may lead to pronounced wage effects in the new member states, which get better access to a big market potential. 
Are there Border Effects in the EU Wage Function? 20

\section{REFERENCES}

Beck, Guenter W. and axel A. Weber (2003) "How Wide Are European Borders? On the Integration Effects of Monetary Unions", Center for Financial Studies an der Johann Wolfgang Universität, Framkfurt/Main, Working Paper No. 2001/07.

Brakman, Steven, Harry Garretsen,and Marc, Schramm, 2004. "The Spatial Distribution of Wages: Estimating the Helpman-Hanson Model for Germany", Journal of Regional Science, 44, pp. 437-66

Brülhart, Marius, Crozet, Mathieu, Koenig, Pamina 2004." Enlargement and the EU periphery: the Impact of Changing Market Potential", World Economy, 27, 853 875 .

Combes, Pierre-Philippe and Miren Lafourcade 2001. "Transport Cost Decline and Regional Inequalities: Evidence from France", C.E.P.R. Discussion Papers, DP 2894 .

Crozet, Matthieu and Pamina Koenig-Soubeyran 2002.” EU Enlargement and industrial relocation within the CEECs", Journal of Comparative Economics, 32, 265 - 279.

De Bruyne, Karolin 2003. "The location of economic activity. Is there a spatial employment structure in Belgium?", manuscript CES-KULeuven, Leuven.

Fujita Masahisa, Paul Krugman and Anthony J. Venables 1999. "The Spatial Economy", MIT-Press, Cambridge, Massachusetts.

Harris, C. 1954. "The market as a factor in the localisation of industry in the United States", Annals of the Association of American Geographers 44, 315-348. 
Are there Border Effects in the EU Wage Function? 21

Hanson, Gordon H. 2005. "Market Potential, Increasing Returns, and Geographic Concentration", Journal of International Economics 67, 1-24.

Head, Kieth and Thierry Mayer (2005) Regional Wage and employment Responses to Market Potential in the EU, CEPR Working Paper No. 4908

Helpman, Elhanan. 1998. "The Size of Regions", in: D. Pines, E. Dadka and I. Zilcha (eds.), Topics in Public Economics, Cambridge University Press.

Kelejian, Harry H. and Ingmar R. Prucha 1999. "A Generalized Method of Moments Estimator for the Autoregressive Parameter in a Spatial Model", International Economic Review 40, pp. 509-533.

Kelejian, Harry H. and Ingmar R. Prucha 2001. "On the Asymptotic Distribution of the Moran I Test Statistic with Applications", Journal of Econometrics 104, , pp. 219-257.

Kelejian, Harry H. and Ingmar R. Prucha 2005. "Specification and Estimation of Spatial Autoregressive Models with Autoregressive and Heteroskedastic Disturbances", Department of Economics, University of Maryland.

Krugmann Paul 1991. "Geography and Trade", MIT-Press, Cambridge, Masachusetts.

Krugman, Paul 1991a. "Increasing Returns and Economic Geography", Journal of Political Economy 3, 383-499.

Krugman, Paul and Raul Livas-Elizondo 1996. "Trade policy and the third world metropolis", Journal of Development Economics, 49, 137 - 150.

Mion, Giordano 2004. "Spatial externalities and empirical analysis". The case of Italy, Journal of Urban Economics 57, 97-118. 


\section{Are there Border Effects in the EU Wage Function? 22}

Niebuhr, Annekatrin 2004. "Market Access and Regional Disparities". New Economic Geography in Europe. HWWA Discussion Paper No.269, Hamburg.

Niebuhr, Annekatrin 2005, "The Impact of EU Enlargement on European Border Regions". HWWA Discussion Paper No.330, Hamburg.

Nitsch, Volker (2000) National borders and international trade: evidence from the European Union, Canadian Journal of Economics, Vol 33/4, pp 1091-1105Roos, Michael 2001. "Wages and Market Potential in Germany", Jahrbuch für Regionalwissenschaft 21, 171-195.

Paluzzie, Elisenda 2001. "Trade Policy and regional inequalities", Papers in Regional Science 80, 67-85. 


\section{Appendix:}

We approximate both the left and right hand side of the market potential function

$$
\begin{aligned}
\ln \left(w_{i}\right)= & \frac{1-\sigma}{\sigma \mu} \ln (\bar{\omega}) \\
& +\frac{1}{\sigma} \ln \left(y_{i} w_{i}^{\frac{\sigma-1}{\mu}}+\sum_{j \neq i}^{N} y_{j} w_{j}^{\frac{\sigma-1}{\mu}} f\left(d_{i j}\right)^{\sigma-1}\right)
\end{aligned}
$$

linearly at the means of $w_{i}$ and $y_{i}$ using $\sum_{j \neq i}^{N} f\left(d_{i j}\right)^{\sigma-1} \approx \rho$ :

$$
\begin{aligned}
& \ln \bar{w}+\frac{\left(w_{i}-\bar{w}\right)}{\bar{w}} \\
& \approx \frac{1-\sigma}{\sigma \mu} \ln (\bar{\omega})+\frac{1}{\sigma} \ln \left(\overline{y w}^{\frac{\sigma-1}{\mu}}(1+\rho)\right)
\end{aligned}
$$

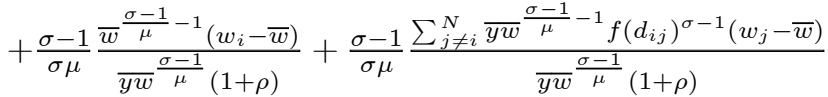

$$
\begin{aligned}
& +\frac{1}{\sigma} \frac{\frac{{ }^{\frac{\sigma-1}{\mu}}}{\mu}\left(y_{i}-\bar{y}\right)}{\overline{y w} \frac{\sigma-1}{\mu}(1+\rho)}+\frac{1}{\sigma} \frac{\sum_{j \neq i}^{N} \bar{w}^{\frac{\sigma-1}{\mu}} f\left(d_{i j}\right)^{\sigma-1}\left(y_{j}-\bar{y}\right)}{\overline{y w} \frac{\sigma-1}{\mu}(1+\rho)} \\
& =\frac{1-\sigma}{\sigma \mu} \ln (\bar{\omega})+\frac{1}{\sigma} \ln \left((1+\rho) \overline{y w}^{\frac{\sigma-1}{\mu}}\right) \\
& +\frac{\sigma-1}{(1+\rho) \sigma \mu} \frac{w_{i}-\bar{w}}{\bar{w}}+\frac{\sigma-1}{(1+\rho) \sigma \mu} \sum_{j \neq i}^{N} \frac{f\left(d_{i j}\right)^{\sigma-1}\left(w_{j}-\bar{w}\right)}{\bar{w}} \\
& +\frac{1}{(1+\rho) \sigma} \frac{y_{i}-\bar{y}}{\bar{y}}+\frac{1}{(1+\rho) \sigma} \sum_{j \neq i}^{N} \frac{f\left(d_{i j}\right)^{\sigma-1}\left(y_{j}-\bar{y}\right)}{\bar{y}}
\end{aligned}
$$

Denoting $\widetilde{x}_{i}$ as the percentage deviation of $x_{i}$ from its mean $\bar{x}$ (i.e. $\widetilde{x}=\frac{x_{i}-\bar{x}}{\bar{x}}, x_{i} \in$ $\left.\left\{\pi_{i}, w_{i}, y_{i}\right\}\right)$ and substituting for $\sum_{j \neq i}^{N} f\left(d_{i j}\right)^{\sigma-1}$ we get

$$
\begin{aligned}
& \ln \bar{w}+\widetilde{w}_{i} \\
\approx & \frac{1-\sigma}{\sigma \mu} \ln (\bar{w})+\frac{1}{\sigma} \ln \left(\overline{y w}^{\frac{\sigma-1}{\mu}}(1+\rho)\right)+\frac{\sigma-1}{\sigma \mu(1+\rho)} \widetilde{w}_{i}
\end{aligned}
$$


Are there Border Effects in the EU Wage Function? 24

$$
\begin{aligned}
& +\frac{\rho_{0}(\sigma-1)}{(1+\rho) \sigma \mu} \sum_{j \neq i \text { and } i j \in \mathcal{F}_{0}} \Theta_{i j}^{0} \widetilde{w}_{j}+\frac{\rho_{E U}(\sigma-1)}{(1+\rho) \sigma \mu} \sum_{j \neq i \text { and } i j \in \mathcal{F}_{E U}} \Theta_{i j}^{E U} \widetilde{w}_{j} \\
& +\frac{\rho_{N E U}(\sigma-1)}{(1+\rho) \sigma \mu} \sum_{j \neq i \text { and } i j \in \mathcal{F}_{N E U}} \Theta_{i j}^{N E U} \widetilde{w}_{j}+\frac{1}{\sigma(1+\rho)} \widetilde{y}_{i} \\
& +\frac{\rho_{0}}{\sigma(1+\rho)} \sum_{j \neq i \text { and } i j \in \mathcal{F}_{0}} \Theta_{i j}^{0} \widetilde{y}_{j}+\frac{\rho_{E U}}{\sigma(1+\rho)} \sum_{j \neq i \text { and } i j \in \mathcal{F}_{E U}} \Theta_{i j}^{E U} \widetilde{y}_{j} \\
& +\frac{\rho_{N E U}}{\sigma(1+\rho)} \sum_{j \neq i \text { and } i j \in \mathcal{F}_{N E U}} \Theta_{i j}^{N E U} \widetilde{y}_{j},
\end{aligned}
$$

where $\Theta_{i j}^{0}=\frac{e^{-\alpha d_{i j}}}{c}$ if $i j \in \mathcal{F}_{0}, \Theta_{i j}^{E U}=\frac{e^{-\alpha d_{i j}}}{c}$ for $i j \in \mathcal{F}_{E U}$, and $\Theta_{i j}^{N E U}=\frac{e^{-\alpha d_{i j}}}{c}$ $i j \in \mathcal{F}_{N E U}$. Collecting terms and rearranging gives the basic specification to be estimated:

$$
\begin{aligned}
\widetilde{w}_{i}= & K+\frac{\rho_{0}(\sigma-1)}{1+\sigma(\mu(1+\rho)-1)} \sum_{j \neq i \text { and } i j \in \mathcal{F}_{0}} \Theta_{i j}^{0} \widetilde{w}_{j} \\
& +\frac{\rho_{E U}(\sigma-1)}{1+\sigma(\mu(1+\rho)-1)} \sum_{j \neq i \text { and } i j \in \mathcal{F}_{E U}} \Theta_{i j}^{E U} \widetilde{w}_{j} \\
& +\frac{\rho_{N E U}(\sigma-1)}{1+\sigma(\mu(1+\rho)-1)} \sum_{j \neq i \text { and } i j \in \mathcal{F}_{0}} \Theta_{i j}^{N E U} \widetilde{w}_{j} \\
& +\frac{\mu}{1+\sigma(\mu(1+\rho)-1)} \widetilde{y}_{i}+\frac{\rho_{0} \mu}{1+\sigma(\mu(1+\rho)-1)} \sum_{j \neq i \text { and } i j \in \mathcal{F}_{0}} \Theta_{i j}^{0} \widetilde{y}_{j} \\
& +\frac{\rho_{E U} \mu}{1+\sigma(\mu(1+\rho)-1)} \sum_{j \neq i} \Theta_{i j}^{E U} \widetilde{y}_{j} \\
& +\frac{\rho_{N E U} \mu}{1+\sigma(\mu(1+\rho)-1)} \sum_{j \neq i \text { and } i j \in \mathcal{F}_{N E U}} \Theta_{i j}^{N E U} \widetilde{y}_{j},
\end{aligned}
$$

where $K=\frac{\sigma \mu(1+\rho)}{1+\sigma(\mu(1+\rho)-1)}\left[\frac{1-\sigma}{\sigma \mu} \ln (\bar{\omega})+\frac{\sigma(1-\mu)-1}{\sigma \mu} \ln \bar{w}+\frac{1}{\sigma} \ln (1+\rho) \bar{y}\right]$. 
Are there Border Effects in the EU Wage Function? 25

\section{Notes}

\footnotetext{
${ }^{1}$ The Helpman (1998) version of the model includes housing prices as an additional determinant of nominal wages. We skip them to simplify the exposition as they are unobserved in our data.
}

${ }^{2}$ To see this consider a region with a distance of say 500 kilometers to all other regions and compare it to a second one, which is located $1000 \mathrm{~km}$ away from the other regions. With a row normalized spatial weighting matrix both regions exhibit the same distribution of spatial weights. Hence, both regions face the same market potential which is at odds with the theoretical model. In our setting, the second region exhibits a smaller market potential, because it is more distant to the others regions as compared to the first one.

${ }^{3}$ The linear approximation of the market potential function is a common strategy in applied work (see Combes and Lafourcade, 2001 and Mion, 2003 for recent examples.)

${ }^{4}$ We checked whether this procedure changes qualitative results and found that this is not the case

${ }^{5}$ This choice was guided by the combination of data availability and the attempt to eliminate some of the short run fluctuations from the data as well as basing estimates on the most recent time period available.

${ }^{6}$ This 'reduced form' may also be interpreted as an estimate of the market potential function as originally formulated by Harrs (1954). 


\section{Are there Border Effects in the EU Wage Function? 26}

${ }^{7}$ For Model 4 the estimates of $\phi$ are those derived for Model 3.

${ }^{8}$ We also looked at a number of smaller spatial decays to check for robustness of our results. In general this does not have a strong impact om findings.Since, specifications with $\alpha=1 / 100$ produce the best fit, we concentrate on this case.

${ }^{9}$ These results are available from the authors upon request.

${ }^{10}$ With these parameter estimates it is no surprise that Model 3 rejects the restrictions imposed on Model 4, although not at an 1\% level of significance.

${ }^{11}$ These qualitative results are consistent with estimtes in Niebuhr (2004) based on a model estimated for the EU15 regions. 


\section{CESifo Working Paper Series}

(for full list see www.cesifo-group.de)

1820 Jan K. Brueckner and Raquel Girvin, Airport Noise Regulation, Airline Service Quality, and Social Welfare, October 2006

1821 Sijbren Cnossen, Alcohol Taxation and Regulation in the European Union, October 2006

1822 Frederick van der Ploeg, Sustainable Social Spending in a Greying Economy with Stagnant Public Services: Baumol's Cost Disease Revisited, October 2006

1823 Steven Brakman, Harry Garretsen and Charles van Marrewijk, Cross-Border Mergers \& Acquisitions: The Facts as a Guide for International Economics, October 2006

1824 J. Atsu Amegashie, A Psychological Game with Interdependent Preference Types, October 2006

1825 Kurt R. Brekke, Ingrid Koenigbauer and Odd Rune Straume, Reference Pricing of Pharmaceuticals, October 2006

1826 Sean Holly, M. Hashem Pesaran and Takashi Yamagata, A Spatio-Temporal Model of House Prices in the US, October 2006

1827 Margarita Katsimi and Thomas Moutos, Inequality and the US Import Demand Function, October 2006

1828 Eytan Sheshinski, Longevity and Aggregate Savings, October 2006

1829 Momi Dahan and Udi Nisan, Low Take-up Rates: The Role of Information, October 2006

1830 Dieter Urban, Multilateral Investment Agreement in a Political Equilibrium, October 2006

1831 Jan Bouckaert and Hans Degryse, Opt In Versus Opt Out: A Free-Entry Analysis of Privacy Policies, October 2006

1832 Wolfram F. Richter, Taxing Human Capital Efficiently: The Double Dividend of Taxing Non-qualified Labour more Heavily than Qualified Labour, October 2006

1833 Alberto Chong and Mark Gradstein, Who's Afraid of Foreign Aid? The Donors' Perspective, October 2006

1834 Dirk Schindler, Optimal Income Taxation with a Risky Asset - The Triple Income Tax, October 2006 
1835 Andy Snell and Jonathan P. Thomas, Labour Contracts, Equal Treatment and WageUnemployment Dynamics, October 2006

1836 Peter Backé and Cezary Wójcik, Catching-up and Credit Booms in Central and Eastern European EU Member States and Acceding Countries: An Interpretation within the New Neoclassical Synthesis Framework, October 2006

1837 Lars P. Feld, Justina A.V. Fischer and Gebhard Kirchgaessner, The Effect of Direct Democracy on Income Redistribution: Evidence for Switzerland, October 2006

1838 Michael Rauscher, Voluntary Emission Reductions, Social Rewards, and Environmental Policy, November 2006

1839 Vincent Vicard, Trade, Conflicts, and Political Integration: the Regional Interplays, November 2006

1840 Erkki Koskela and Mikko Puhakka, Stability and Dynamics in an Overlapping Generations Economy under Flexible Wage Negotiation and Capital Accumulation, November 2006

1841 Thiess Buettner, Michael Overesch, Ulrich Schreiber and Georg Wamser, Taxation and Capital Structure Choice - Evidence from a Panel of German Multinationals, November 2006

1842 Guglielmo Maria Caporale and Alexandros Kontonikas, The Euro and Inflation Uncertainty in the European Monetary Union, November 2006

1843 Jan K. Brueckner and Ann G. Largey, Social Interaction and Urban Sprawl, November 2006

1844 Eytan Sheshinski, Differentiated Annuities in a Pooling Equilibrium, November 2006

1845 Marc Suhrcke and Dieter Urban, Are Cardiovascular Diseases Bad for Economic Growth?, November 2006

1846 Sam Bucovetsky and Andreas Haufler, Preferential Tax Regimes with Asymmetric Countries, November 2006

1847 Luca Anderlini, Leonardo Felli and Andrew Postlewaite, Should Courts always Enforce what Contracting Parties Write?, November 2006

1848 Katharina Sailer, Searching the eBay Marketplace, November 2006

1849 Paul De Grauwe and Pablo Rovira Kaltwasser, A Behavioral Finance Model of the Exchange Rate with Many Forecasting Rules, November 2006

1850 Doina Maria Radulescu and Michael Stimmelmayr, ACE vs. CBIT: Which is Better for Investment and Welfare?, November 2006 
1851 Guglielmo Maria Caporale and Mario Cerrato, Black Market and Official Exchange Rates: Long-Run Equilibrium and Short-Run Dynamics, November 2006

1852 Luca Anderlini, Leonardo Felli and Andrew Postlewaite, Active Courts and Menu Contracts, November 2006

1853 Andreas Haufler, Alexander Klemm and Guttorm Schjelderup, Economic Integration and Redistributive Taxation: A Simple Model with Ambiguous Results, November 2006

1854 S. Brock Blomberg, Thomas DeLeire and Gregory D. Hess, The (After) Life-Cycle Theory of Religious Contributions, November 2006

1855 Albert Solé-Ollé and Pilar Sorribas-Navarro, The Effects of Partisan Alignment on the Allocation of Intergovernmental Transfers. Differences-in-Differences Estimates for Spain, November 2006

1856 Biswa N. Bhattacharyay, Understanding the Latest Wave and Future Shape of Regional Trade and Cooperation Agreements in Asia, November 2006

1857 Matz Dahlberg, Eva Mörk, Jørn Rattsø and Hanna Ågren, Using a Discontinuous Grant to Identify the Effect of Grants on Local Taxes and Spending, November 2006

1858 Ernesto Crivelli and Klaas Staal, Size and Soft Budget Constraints, November 2006

1859 Jens Brøchner, Jesper Jensen, Patrik Svensson and Peter Birch Sørensen, The Dilemmas of Tax Coordination in the Enlarged European Union, November 2006

1860 Marcel Gérard, Reforming the Taxation of Multijurisdictional Enterprises in Europe, "Coopetition" in a Bottom-up Federation, November 2006

1861 Frank Blasch and Alfons J. Weichenrieder, When Taxation Changes the Course of the Year - Fiscal Year Adjustments and the German Tax Reform 2000/2001, November 2006

1862 Hans Jarle Kind, Tore Nilssen and Lars Sørgard, Competition for Viewers and Advertisers in a TV Oligopoly, November 2006

1863 Bart Cockx, Stéphane Robin and Christian Goebel, Income Support Policies for PartTime Workers: A Stepping-Stone to Regular Jobs? An Application to Young LongTerm Unemployed Women in Belgium, December 2006

1864 Sascha O. Becker and Marc-Andreas Muendler, The Effect of FDI on Job Separation, December 2006

1865 Christos Kotsogiannis and Robert Schwager, Fiscal Equalization and Yardstick Competition, December 2006

1866 Mikael Carlsson, Stefan Eriksson and Nils Gottfries, Testing Theories of Job Creation: Does Supply Create Its Own Demand?, December 2006 
1867 Jacques H. Drèze, Charles Figuières and Jean Hindriks, Voluntary Matching Grants Can Forestall Social Dumping, December 2006

1868 Thomas Eichner and Marco Runkel, Corporate Income Taxation of Multinationals and Unemployment, December 2006

1869 Balázs Égert, Central Bank Interventions, Communication and Interest Rate Policy in Emerging European Economies, December 2006

1870 John Geweke, Joel Horowitz and M. Hashem Pesaran, Econometrics: A Bird's Eye View, December 2006

1871 Hans Jarle Kind, Marko Koethenbuerger and Guttorm Schjelderup, Taxation in TwoSided Markets, December 2006

1872 Hans Gersbach and Bernhard Pachl, Cake Division by Majority Decision, December 2006

1873 Gunther Schnabl, The Evolution of the East Asian Currency Baskets - Still Undisclosed and Changing, December 2006

1874 Horst Raff and Michael J. Ryan, Firm-Specific Characteristics and the Timing of Foreign Direct Investment Projects, December 2006

1875 Jukka Pirttilä and Håkan Selin, How Successful is the Dual Income Tax? Evidence from the Finnish Tax Reform of 1993, December 2006

1876 Agnieszka Stążka, Sources of Real Exchange Rate Fluctuations in Central and Eastern Europe - Temporary or Permanent?, December 2006

1877 Xavier Calsamiglia, Teresa Garcia-Milà and Therese J. McGuire, Why do Differences in the Degree of Fiscal Decentralization Endure?, December 2006

1878 Natacha Gilson, How to be Well Shod to Absorb Shocks? Shock Synchronization and Joining the Euro Zone, December 2006

1879 Scott Alan Carson, Modern Health Standards for Peoples of the Past: Biological Conditions by Race in the American South, 1873 - 1919, December 2006

1880 Peter Huber, Michael Pfaffermayr and Yvonne Wolfmayr, Are there Border Effects in the EU Wage Function?, December 2006 